\title{
Kooli mikrokliima: õpetajate toetav käitumine ja õpilaste tulemuslikkus
}

\author{
Maie Kitsingal, Karin Täht ${ }^{\mathrm{b}}$, Hasso Kukemelk ${ }^{\mathrm{a}}$ \\ a Tartu Ülikooli haridusteaduste instituut \\ b Tartu Ülikooli psühholoogia instituut
}

\begin{abstract}
Annotatsioon
Uuringu eesmärk oli selgitada õpetaja toetava käitumise ja õpilase õppetööd takistava käitumise seoseid õpilaste õpitulemustega, arvestades õpilaste sotsiaalmajanduslikku tausta. Valimi moodustasid PISA 2012. aasta uuringus osalenud eesti õppekeelega koolide 3570 õpilast ja nende koolide juhid. Töös kasutati nelja PISA 2012. aasta andmebaasi muutujat: 1) õpilaste keskmist tulemust kolmes hindamisvaldkonnas (matemaatika, loodusteadused, kirjutamine); 2) õpilaste sotsiaalmajanduslikku tausta; 3) õpilaste käitumise indeksit, mis koondas õpilastega seotud õppetööd häirivad tunnused; 4) õpetajate käitumist iseloomustavaid tunnuseid, mis takistavad õppetööd.

Uurimistulemustest ilmnes statistiliselt oluline, kuid väga nõrk seos õpilaste keskmise soorituse ja õpetajatepoolse õppetööd takistava käitumise vahel. Õpilasteja õpetajatepoolse õppetööd takistava käitumise seos oli mõõdukas. Sotsiaalmajandusliku tausta põhjal prognoositust madalama ja kõrgema tulemuse saanud õpilaste gruppide puhul avaldus mõõdukas seos õpilaste- ja õpetajatepoolse õppetööd takistava käitumise järgmiste tunnuste vahel: õpilaste ja õpetajate halvad suhted (alasooritajate grupis $r=0,54$; ülesooritajate grupis $r=0,51$ ) ja ópetajad ei arvesta iga üksiku õpilase vajadustega (alasooritajate grupis $r=0,40$; ülesooritajate grupis $r=0,43$ ). Alasooritajate grupi puhul osutus mõõdukaks seoseks veel tunnus õpilasi ei julgustata saavutama kogu oma potentsiaali $(r=0,41)$, seevastu ülesooritajate grupis ilmnes mõõdukas seos õpilase käitumise ja õpetaja käitumist iseloomustava tunnuse õpetajad peavad ópetama ühes ja samas klassis erineva etnilise taustaga (st keel, kultuur) ópilasi puhul $(r=0,40)$. Kahe grupi seoste võrdlemisel osutus statistiliselt oluliselt erinevaks kaks tunnust: ópilasi ei julgustata saavutama kogu oma potentsiaali ja õpetajad peavad ópetama ühes ja samas klassis erinevate võimetega õpilasi.
\end{abstract}

Võtmesõnad: õpilaste käitumine, õpetajate käitumine, PISA, kooli mikrokliima, õpilase sotsiaalmajanduslik taust

$1 \quad$ Haridusteaduste instituut, Tartu Ülikool, Salme 1a, 50103 Tartu; maie.kitsing@hm.ee 


\section{Sissejuhatus}

Kooli mikrokliima on üks olulisemaid mõjutegureid soodsa õpikeskkonna kujunemisel. Ühelt poolt mõjutab mikrokliima õpilaste teadmiste ja oskuste ning emotsionaalse, eetilise ja sotsiaalse kompetentsi omandamist (Bodovski, Nahum-Shani, \& Walsh, 2013; Cohen \& Elias, 2010). Teisalt mõjutab kooli mikrokliima õpetajate tööd ja suhtlust koolis - nii õpilastevahelist suhtlust kui ka suhtlust õpilaste ja õpetajate vahel (Caldarella, Shatzer, Gray, Young, \& Young, 2011; Willmore, 2006). Kooli mikrokliima valdkonna käsitlemisel on uurijatel olnud erinevad rõhuasetused. Üldjoontes võib jagada kooli mikrokliima kolmeks: 1) õpetajate ja juhtidega seotud temaatika (õpetaja ootused ja tajud seoses õpilastega, iga õpilase individuaalsuse arvestamine, töö ja kutsevalikuga rahulolu, kooli eestvedamine, kooli korrast kinnipidamine jms) (Brown \& Henry, 1992; Kitsing, Ploom, \& Kukemelk, 2013; Robinson, Hohepa, \& Lloyd, 2009; Voltri, Luik, \& Taimalu, 2013); 2) õpilastega seotud temaatika (distsipliin ja koolivägivald, õppetundidest puudumine, motivatsioon, õpilaste kaasatus otsustusprotsessi ja osalus otsustusprotsessis, õpilaste kuuluvustunne, rahulolu, suhtumine kooli jms) (Cohen, 2006; Jõgi, Aus, \& Kikas, 2014; Klein, Cornell, \& Konold, 2012; Patton et al., 2006; Ruus et al., 2007; Täht, 2012); 3) koolihoonega ja koolitöö üldise toimimisega seonduvad tunnused (Freiberg, 1999). PISA uuringutes käsitletakse kooli mikrokliimat mitme tunnuse kaudu, mida on kirjeldatud koolijuhtide hinnangutest saadud andmete põhjal. Siinses töös võeti aluseks PISA 2012. aasta uuringus kasutatud tõlgendus, mille kohaselt hõlmab mikrokliima mõiste õpetajate ja õpilaste käitumist, õpetajate moraali ja õpilaste distsipliini. Töös keskenduti kahele alavaldkonnale: õppetööd takistavale õpetaja ja õpilase käitumisele (OECD, 2013c).

Õpilased tajuvad üsna selgelt kooli mikrokliimat, kus õpilast ei toetata ja kus nende rahulolu on vähene. Negatiivse mikrokliima tunnustena toovad õpilased esile näiteks halbu suhteid õpilaste ja õpetajate vahel, „ülevalt alla” suhtumist õpilastesse, koolivägivalda, halva käitumisega õpilasi, õpetajate madalaid ootusi nende suhtes ning vähest huvi nende käekäigu vastu (Osler, 2010; Shepard et al., 2012). Feldman ja Theiss (1980) on väitnud, et õpilased ja õpetajad mõjutavad üksteist oma käitumise kaudu.

Mitmed uurijad on jõudnud veendumusele, et igas koolis on mikrokliima omanäoline (Loukas, 2007; Wang et al., 2014). Kooli mikrokliimat kujundavad mitmed asjaolud. Ühelt poolt mõjutab kooli mikrokliima kujunemist õpilaste sotsiaalmajanduslik taust (edaspidi: $\mathrm{SES}^{2}$ ), mille kohta on

2 Rahvusvaheline lühend õpilase sotsiaalmajandusliku tausta kirjeldamisel, tuleneb ingliskeelsest väljendist socioeconomic status. 
uurijad leidnud olulisi seoseid õpilaste tulemustega (Baird, 2012; Brookover et al., 1978; Null, 2013). Teiselt poolt on mikrokliimaga seotud teguriteks mitmed õpetajate käitumise aspektid (Cohen, McCabe, Michelli, \& Pickeral, 2009; Devine \& Cohen, 2007). Õpilaste SES-tegurite mõjutamiseks koolidel võimalused enamasti puuduvad, küll aga on võimalik pöörata tähelepanu õpetajate tegevusele ja seda suunata. Mitmed uurijad soovitavad parandada õpetaja suhteid õpilastega, sest õpetajate ja õpilaste head suhted toetavad akadeemilist edukust, eriti nooremas koolieas (Capern \& Hammond, 2014; Schmitt, Pentimonti, \& Justice, 2012). Samuti saab muuta õpetajate suhtumist õpilastesse positiivsemaks, tagades õpetajatele vajalikud teadmised (Scanlon \& Barnes-Holmes, 2013). Väljavaateid mikrokliima kujundamiseks ja õpiedukuse soodustamiseks õpetajate toetava käitumise abil aitaks selgitada uuring, kus õpetaja käitumise seoseid õppimise tulemustega ja õpilaste käitumisega analüüsitakse, võttes seose leidmisel arvesse õpilaste SES-tausta varieerumist.

Enamiku PISA 2012. aasta uuringus osalenud riikidega võrreldes on Eestis koolide vahel ópilaste tulemused üsna sarnased, kuid Soomega võrreldes on meil koolide vahel ligikaudu kaks korda suurem erinevus (OECD, 2013c). Samas saab mõlema riigi puhul üsna sarnaselt selgitada õpilaste SES-tausta kaudu matemaatika tulemuste varieeruvust (Eestis 8,6\%, Soomes 9,4\%) (OECD, 2013b). Selle põhjal võib oletada, et koolide õppetöös ja õpikeskkonnas, sh õppetööd mõjutavates tegurites, on erinevusi.

Arvestades kooli mikrokliima mõju õpilaste tulemustele, on oluline selgitada, mida koolid, kus õpilased saavutavad kõrgemaid tulemusi, teevad kooli mikrokliima valdkonnas teisiti võrreldes koolidega, kus saavutused on nõrgemad. Töö eesmärk on selgitada õpetaja toetava käitumise ja õpilasepoolse õppetööd takistava käitumise seoseid õpilaste õpitulemustega, arvestades õpilaste sotsiaalmajanduslikku tausta. Eesmärgi täitmiseks püstitati järgmised uurimisküsimused.

1. Mis seosed on õpetajatepoolse õppetööd takistava käitumise ja õpilaste õpitulemuste vahel?

2. Mis seosed on sotsiaalmajandusliku tausta põhjal prognoositud õpilaste üle- või alasoorituse ja õpetajatepoolse õppetööd takistava käitumise vahel?

3. Kas seosed õpetajate- ja õpilastepoolse õppetööd takistava käitumise vahel ala- ja ülesooritajate grupis on sarnased?

4. Kui palju kirjeldab õpilastepoolse õppetööd takistava käitumise varieeruvusest õpetajatepoolne õppetööd takistav käitumine? 


\section{Meetod}

\section{Valim}

Töös kasutati PISA 2012. aasta eesti õppekeelega koolide õpilaste valimit ( $N=3570,50 \%$ tüdrukud), kuhu kuulusid õpilased vanusevahemikus 15 aastat ja 3 kuud kuni 16 aastat ja 2 kuud. PISA 2012 valim moodustati kaheastmeliselt: esmalt valiti välja uuringus osalevad koolid $(N=206)$, seejärel valiti juhuvaliku alusel õpilased (kuni 35 ühest koolist). Koolivõrgu suhtes esinduslikkuse tagamiseks arvestati koolide valikul nende jaotumist asukoha, suuruse ja tüübi alusel ning õppekeeliti (Tire et al., 2013). Hoidmaks ära rahvuslikust ja kultuurilisest taustast tingitud mikrokliima iseloomustamise varieerumist, võeti uurimistöö valimisse ainult eesti õppekeelega koolid. Õpilased jagati kolme gruppi, lähtudes SESi alusel prognoositud tulemuslikkuse prognoosijääkidest (residuals):

1) õpilased, kelle kolme hindamisvaldkonna keskmine sooritus oli oodatust nõrgem, kui eeldanuks nende sotsiaalmajanduslik taust (edaspidi: alasooritajad);

2) õpilased, kes saavutasid kolme hindamisvaldkonna prognoositud tulemusele lähedase tulemuse (edaspidi: ootuspärased sooritajad); keskmise grupi liikmete eristamise kriteeriumiks oli üks prognoosijääkide standardhälve;

3) õpilased, kelle kolme hindamisvaldkonna keskmine sooritus oli parem kui prognoositud keskmine sooritus (edaspidi: ülesooritajad).

Kaks äärmusgruppi (üle- ja alasooritajate grupid) on õpilaste arvult sarnased, kuid alasooritajate grupis on poiste ülekaal ja ülesooritajate grupis tüdrukute väike osakaal. Ootuspäraste sooritajate grupp on õpilaste arvult suurim ja sooline jaotus üsna ühtlane (tabel 1).

Tabel 1. Sooline jaotus valitud kolmes grupis

\begin{tabular}{l|c|c|c|c|c}
\hline & $\begin{array}{c}\text { Tüdrukud } \\
\boldsymbol{N}\end{array}$ & $\begin{array}{c}\text { Tüdrukute } \\
\text { osakaal \% }\end{array}$ & $\begin{array}{c}\text { Poisid } \\
\boldsymbol{N}\end{array}$ & $\begin{array}{c}\text { Poiste } \\
\text { osakaal \% }\end{array}$ & $\begin{array}{c}\text { Kokku } \\
\boldsymbol{N}\end{array}$ \\
\hline Grupp 1 - alasooritajad & 218 & 38 & 357 & 62 & 575 \\
\hline $\begin{array}{l}\text { Grupp 2 - ootuspärased } \\
\text { sooritajad }\end{array}$ & 1279 & 53 & 1135 & 47 & 2414 \\
\hline Grupp 3 - ülesooritajad & 319 & 55 & 262 & 45 & 581 \\
\hline
\end{tabular}

Märkus. $N=$ õpilaste arv. 


\section{Mõõtevahendid ${ }^{3}$}

Õpilase sooritus, mida iseloomustati PISA 2012 uuringus hinnatud kolme valdkonna - matemaatika, loodusteaduste ja lugemise - soorituse keskmisega. Kolme hindamisvaldkonna keskmist kasutati seetõttu, et õpilaste üle- ja alasooritus ei oleks väga tugevalt seotud ühe hindamisvaldkonnaga, vaid näitaks üldisemalt õpilaste sooritustaset. Muutuja arvutamisel kasutati PISA 2012 riigisiseses andmebaasis olevaid eesti õppekeelega koolide õpilaste keskmisi sooritusi kolmes hindamisvaldkonnas $(M=537, S D=75,05$, $N=3570$ ). Arvutatud prognoosijääkide põhjal moodustati kolm gruppi: alasooritajad, ootuspärased sooritajad ja ülesooritajad. Gruppide eraldamise aluseks võeti üks standardhälbe punkt - ootuspärased sooritajad jäid ühe standardhälbe punkti piiresse.

Õpilase sotsiaalmajanduslik taust $(M=0,18, S D=0,81, N=3568)$. Iga õpilase punktisumma kujunes kolme tunnuse põhjal, kusjuures vastajateks olid õpilased:

1) vanemate tööalane staatus $(M=52,71, S D=20,99, N=3512)$. Vastused kodeeriti ISCO ${ }^{4}$ nelja gruppi (ILO, 1990) ning korrutati läbi Ganzeboomi, Graafi ja Treimani (1992) SEI indeksiga;

2) vanemate haridus $(M=13,60, S D=2,13, N=3523)$. Vanemate hariduse klassifitseerimiseks kasutati ISCEDd ${ }^{5}$ (OECD, 1999). Vanemate haridustaseme näitajana kasutati kõrgeimat haridustaset, mis ühel või teisel vanemal oli (OECD, 2013a);

3) kodune materiaalne heaolu $(M=0,16, S D=0,88, N=3570)(\mathrm{OECD}$, 2013a), mis määrati kindlaks kolme muutuja põhjal: a) vanemate jõukus $(M=-0,14, S D=0,83, N=3569)$, st kas õpilastel on kodus oma ruum, juurdepääs internetti, nõudepesumasin, telerid, autod jms; b) kodused õpitingimused ( $M=0,30, S D=0,9, N=3568)$, st kas õpilastel on kodus oma õppimislaud, arvuti, kus nad saavad kodutöid teha, sõnaraamatud jms; c) kodu kultuuriline kapital $(M=0,42, S D=0,93, N=3557)$, st kas õpilastel on kodus kirjandusklassikat, luuleraamatuid ja kunstiteoseid (nt maalid) (OECD, 2013a).

Õpilastepoolne õppetööd takistav käitumine, mille tunnused kujunesid PISA 2012 uuringus koolijuhtide küsimustiku baasil. Uurimistöös määrati iga juhi vastused vaatlusaluse kooli õpilaste üheks tunnuseks. Koolijuht vastas PISA 2012 uuringus järgmisele küsimusele: „Mis ulatuses on Teie koolis õppetöö takistatud järgmistel põhjustel: õpilaste hilinemine, puudumine

3 Kõigi tunnuste (v.a õpilaste sooritustaseme) iseloomustamisel on kasutatud PISA 2012 riigisisest andmebaasi. Andmebaasi omanik on SA Innove.

4 ISCO - International Standard Classification of Occupations.

5 ISCED - International Standard Classification of Education. 
üksikutest tundidest ja õppepäevadest, õppetunni segamine, õpetajatest lugupidamine, narkootikumide ja alkoholi tarvitamine, kohustuslikel kooliüritustel osalemine ja kiusamine?" Juhid nõustusid iga esitatud väitega neljapallisel Likert-tüüpi skaalal (1 - „nõustun täiesti”; 4 - „ei nõustu üldse”). Töös kasutati eesti õppekeelega koolide PISA 2012 uuringus moodustatud agregeeritud muutujat õppetööd takistava käitumise kohta $(M=-0,07$, $S D=0,88, N=3570$ ). Küsimustiku reliaablus oli hea (Cronbachi $\alpha=0,83$ ). Mida positiivsema väärtusega indeks oli, seda vähem oli õpilastepoolset õppetööd takistavat käitumist. Indeksi negatiivne väärtus viitab, et koolijuhtide arvates on nende koolis õpilastepoolne õppetööd takistav käitumine suurema ulatusega (OECD, 2013c).

Õpetajatepoolne õppetööd takistav käitumine, mille tunnused kujunesid PISA 2012 uuringus kasutatud koolijuhtide küsimustiku baasil. Uurimistöös määrati iga juhi vastused vaatlusaluse kooli õpilaste üheks tunnuseks $(M=0,10, S D=0,87, N=3338)$. Töös kasutati nii õpetajatepoolse õppetööd takistava käitumise agregeeritud muutujat kui ka väiteid, mille põhjal agregeeritud muutuja kujunes. Juht vastas PISA 2012 uuringus järgmisele küsimusele: „Mis ulatuses on Teie koolis õppetöö takistatud järgmistel põhjustel: õpetajad ei julgusta õpilasi potentsiaali avamisel, halvad õpilase ja õpetaja vahelised suhted, õpetaja hakkamasaamine heterogeense võimekusega õpilaste koosõpetamisega ühes ja samas klassis, õpetaja hakkamasaamine erineva etnilise taustaga õpilaste koosõpetamisega ühes ja samas klassis (sh kultuur ja keel), õpetajate madalad ootused õpilaste suhtes, õpilaste individuaalsete vajadustega mittearvestamine, õpetajate puudumine, liigne rangus õpilaste suhtes, vastuseis muutustele, hilinemine, vähene tundideks ettevalmistus?" Juhid nõustusid iga esitatud väitega neljapallisel Likert-tüüpi skaalal ( 1 - „nõustun täiesti”; 4 - „ei nõustu üldse”). Küsimustiku reliaablus oli hea (Cronbachi $\alpha=0,81$ ). Mida positiivsema väärtusega indeks oli, seda vähem oli õpetajatepoolset õppetööd takistavat käitumist. Indeksi negatiivne väärtus viitab, et koolijuhtide arvates on nende koolis õpetajatepoolne õppetööd takistav käitumine suurema ulatusega (OECD, 2013c).

Kooli asukoht, kus õpilane õpib. Piirkonna asustuse ja taristu alusel liigitati kõik koolid kolme rühma: 1) suurlinnakoolid, 2) linnakoolid, 3) vallakoolid või väikelinna koolid. Liigitamisel lähtuti PISA 2012 uuringus kasutatud jaotusest (PISA, 2013b).

\section{Andmete analüüs}

SESi kontekstis erineva õpitulemuste tasemega õpilaste (ülesooritajate, ootuspäraselt sooritajate ja alasooritajate) gruppide kindlaksmääramisel tugineti lineaarse regressioonanalüüsi käigus leitud regressioonijääkidele. 
Regressioonanalüüsiks kasutati andmetöötlusprogrammi SPSS, kusjuures sõltuvaks muutujaks oli õpilaste keskmine sooritus kolmes hindamisvaldkonnas ja sõltumatuks muutujaks õpilaste sotsiaalmajanduslik taust. Regressioonanalüüsi eesmärk oli teha õpilase sotsiaalmajandusliku tausta põhjal kindlaks, kui suur on tema ala- või ülesooritus. Gruppidevahelisi erinevusi on hinnatud aritmeetiliste keskmiste alusel T-testiga.

Korrelatsioonanalüüsiga leiti valitud gruppide õpilaste kolme hindamisvaldkonna soorituste keskmiste ja üle- või alasoorituse seosed õpetajatepoolse õppetööd takistava käitumise agregeeritud muutujaga. Korrelatsioonanalüüsi kasutati ka õpetajate- ja õpilastepoolse õppetööd takistava käitumise agregeeritud muutuja vahelise seose leidmisel. Selgitamaks õpetajate võimaliku käitumise erisust suurema ala- või ülesooritusega õpilaste puhul, võrreldi seose tugevust kahes äärmusgrupis - üle- ja alasooritajate grupis.

Õpilaste käitumist ja hoiakuid selgitavate oluliste tunnuste väljatoomisel kasutati regressioonanalüüsi, kusjuures sõltuvaks muutujaks oli õpilaste keskmine sooritus kolmes hindamisvaldkonnas ja sõltumatuks muutujaks õpilastepoolse õppetööd takistava käitumise agregeeritud muutuja.

\section{Tulemused}

Üle- ja alasooritajate grupi kolme hindamisvaldkonna keskmise vahe oli 214 punkti. Arvestades, et PISA uuringus on üks õppeaasta võrdsustatud 39 punktiga, on erinevus õpilaste teadmistes rohkem kui viis õppeaastat (tabel 2) (OECD, 2013a).

Tabel 2. Kolme grupi kolme hindamisvaldkonna (matemaatika, loodusteaduste, kirjutamise) keskmist iseloomustavad tulemused $(N=3570)$

\begin{tabular}{l|c|c|c|c|c}
\hline & M & SD & Min & Max & N \\
\hline Alasooritajate grupp & 428 & 39,8 & 253 & 506 & 575 \\
\hline Ootuspäraste sooritajate grupp & 538 & 45,5 & 413 & 657 & 2414 \\
\hline Ülesooritajate grupp & 642 & 37,7 & 560 & 779 & 581 \\
\hline
\end{tabular}

Märkus. $M=$ keskmine tulemus; $S D=$ standardhälve; $\min =$ minimaalne tulemus; $\max =$ maksimaalne tulemus; $N=$ õpilaste arv.

Ootuspäraselt sooritanute osakaal oli kõigi kolme asukohatüübi puhul kõige suurem, kuid kui vaadelda ainult äärmusgruppe, siis alasooritajaid oli kõige rohkem valla- või väikelinnakoolides ja ülesooritajaid maakonnakeskustes, mõlemas grupis ca 1/5 õpilastest (tabel 3). 
Tabel 3. Ala- ja ülesooritajate jaotus asukoha järgi $(N=3570)$

\begin{tabular}{l|c|c|c}
\hline & $\begin{array}{c}\text { Alasooritajad } \\
\%\end{array}$ & $\begin{array}{c}\text { Ootuspärased } \\
\text { sooritajad \% }\end{array}$ & $\begin{array}{c}\text { Ülesooritajad } \\
\%\end{array}$ \\
\hline Maakonnakeskused & 14 & 65 & 21 \\
\hline Suurlinnakoolid & 13 & 73 & 14 \\
\hline Vallakoolid või väikelinnakoolid & 20 & 68 & 16 \\
\hline
\end{tabular}

Märkus. $N=$ õpilaste arv.

Selleks, et vastata esimesele ja teisele uurimisküsimusele ${ }^{6}$, uuriti kolmes grupis seoseid õpetajatepoolse õppetööd takistava käitumise agregeeritud muutuja ja õpilaste kolme hindamisvaldkonna keskmise soorituse ning õpilastepoolse õppetööd takistava käitumise agregeeritud muutuja vahel (tabel 4). Kuigi eelnimetatud seosed on väga nõrgad, ilmneb siiski ootuspäraste sooritajate ja ülesooritajate grupis statistiliselt oluline seos õpilaste keskmise soorituse ja õpetajatepoolse õppetööd takistava käitumise vahel. Alasooritajate grupis pole õpilaste tulemused ja õpetajatepoolne õppetööd takistav käitumine statistiliselt oluliselt seotud. Seos kahe agregeeritud muutuja - õpilaste- ja õpetajatepoolse õppetööd takistava käitumise - vahel on mõõdukas, kusjuures seos tugevneb, kui võrrelda kolme gruppi omavahel. Nõrgim mõõdukas seos on alasooritajate grupis, tugevaim ülesooritajate grupis.

Tabel 4. Korrelatsioonikordajad õpetajatepoolse õppetööd takistava käitumise ja õpilaste kolme hindamisvaldkonna keskmise soorituse ning õpilastepoolse õppetööd takistava käitumise vahel

\begin{tabular}{l|c|c}
\hline & $\begin{array}{c}\text { Õpilaste soori- } \\
\text { tuse kolme vald- } \\
\text { konna keskmine }\end{array}$ & $\begin{array}{c}\text { Õpilastepoolne } \\
\text { oppetööd takis- } \\
\text { tav käitumine }\end{array}$ \\
\hline Õpetaja käitumine alasooritajate grupis & $-0,04$ & $\mathbf{0 , 5 6 * *}$ \\
\hline Õpetaja käitumine ootuspäraste sooritajate grupis & $\mathbf{0 , 0 9 * *}$ & $\mathbf{0 , 5 9 * *}$ \\
\hline Õpetaja käitumine ülesooritajate grupis & $\mathbf{0 , 1 0 *}$ & $\mathbf{0 , 6 6 * *}$ \\
\hline
\end{tabular}

Märkus. ${ }^{*}=$ Pearsoni korrelatsioonikordaja on oluline nivool $p<0,05 ;{ }^{* *}=$ Pearsoni korrelatsioonikordaja on oluline nivool $p<0,01$.

Kui vaadelda eelnimetatud agregeeritud muutujate seost ala- või ülesoorituse mahuga, mis on leitud prognoosijääkide alusel, siis võib öelda, et õpilaste üle- või alasooritus ei seostu ei õpetajate- ega ka õpilastepoolse õppetööd takistava käitumisega (tabel 5).

6 Mis seosed on õpetajatepoolse õppetööd takistava käitumise ja õpilaste õpitulemuste vahel? Mis seosed on sotsiaalmajandusliku tausta põhjal prognoositud õpilaste üle- või alasoorituse ja õpetajatepoolse õppetööd takistava käitumise vahel? 
Tabel 5. Õpilaste soorituse seosed õpetajate ja nende endi käitumisega (prognoosijääkide alusel)

\begin{tabular}{l|c|c}
\hline & $\begin{array}{c}\text { Õpetajatepoolne } \\
\text { oppetööd takis- } \\
\text { tav käitumine }\end{array}$ & $\begin{array}{c}\text { Õpilastepoolne } \\
\text { oppetööd takis- } \\
\text { tav käitumine }\end{array}$ \\
\hline Alasooritus alasooritajate grupis & 0,00 & 0,01 \\
\hline Ala- või ülesooritus ootuspäraste sooritajate grupis & $\mathbf{0 , 1 0 * *}$ & $\mathbf{0 , 0 9 * *}$ \\
\hline Ülesooritus ülesooritajate grupis & 0,00 & 0,00 \\
\hline
\end{tabular}

Märkus. ${ }^{* *}=$ Pearsoni korrelatsioonikordaja on oluline nivool $p<0,01$.

Kolmandale uurimisküsimusele ${ }^{7}$ vastates uuriti kõigepealt koolijuhtide hinnanguid õpetajatepoolsele õppetööd takistavale käitumisele ala- ja ülesooritajate grupis (tabelid 6 ja 7) ning leiti seosed õpilastepoolse õppetööd takistava käitumise agregeeritud muutuja ja õpetajatepoolse õppetööd takistava käitumise üksiktunnuste vahel (tabel 8).

Tabel 6. Koolijuhtide vastused väidetele õpetajatepoolse õppetööd takistava käitumise kohta alasooritajate grupis

\begin{tabular}{l|c|c|c|c}
\hline Õpetajatepoolse õppetööd takistava käitumise tunnused & $M$ & $S D$ & Min & Max \\
\hline Õpilasi ei julgustata saavutama kogu oma potentsiaali & 2,08 & 0,81 & 1 & 4 \\
\hline Õpilaste ja õpetajate halvad suhted & 1,74 & 0,50 & 1 & 3 \\
\hline $\begin{array}{l}\text { Õpetajad peavad õpetama ühes ja samas klassis erinevate } \\
\text { võimetega õpilasi }\end{array}$ & 2,68 & 0,81 & 1 & 4 \\
\hline $\begin{array}{l}\text { Õpetajad peavad õpetama ühes ja samas klassis erineva } \\
\text { etnilise taustaga (st keel, kultuur) õpilasi }\end{array}$ & 1,6 & 0,77 & 1 & 4 \\
\hline Õpetajatel on õpilaste suhtes madalad ootused & 1,63 & 0,59 & 1 & 3 \\
\hline Õpetajad ei arvesta iga üksiku õpilase vajadustega & 2,07 & 0,68 & 1 & 3 \\
\hline Õpetajate puudumine & 1,57 & 0,68 & 1 & 4 \\
\hline Õpetajate vastuseis muutustele & 1,96 & 0,84 & 1 & 4 \\
\hline Õpetajad on õpilastega liiga ranged & 1,89 & 0,611 & 1 & 4 \\
\hline Õpetajate hilinemine & 1,46 & 0,58 & 1 & 3 \\
\hline Õpetajad ei ole tundideks hästi valmistunud & 1,52 & 0,55 & 1 & 3 \\
\hline
\end{tabular}

Märkus. $M=$ keskmine tulemus; $S D=$ standardhälve; $\min =$ minimaalne tulemus; $\max =$ maksimaalne tulemus.

7 Kas seosed õpetajate- ja õpilastepoolse õppetööd takistava käitumise vahel ala- ja ülesooritajate grupis on sarnased? 
Tabel 7. Koolijuhtide vastused väidetele õpetajatepoolse õppetööd takistava käitumise kohta ülesooritajate grupis

\begin{tabular}{l|c|c|c|c}
\hline Õpetaja käitumise ja hoiakute tunnused & $M$ & $S D$ & Min & Max \\
\hline Õpilasi ei julgustata saavutama kogu oma potentsiaali & 1,83 & 0,81 & 1 & 4 \\
\hline Õpilaste ja õpetajate halvad suhted & 1,48 & 0,52 & 1 & 3 \\
\hline $\begin{array}{l}\text { Õpetajad peavad õpetama ühes ja samas klassis erine- } \\
\text { vate võimetega õpilasi }\end{array}$ & 2,5 & 0,80 & 1 & 4 \\
\hline $\begin{array}{l}\text { Õpetajad peavad õpetama ühes ja samas klassis erineva } \\
\text { etnilise taustaga (st keel, kultuur) õpilasi }\end{array}$ & 1,48 & 0,68 & 1 & 4 \\
\hline Õpetajatel on õpilaste suhtes madalad ootused & 1,41 & 0,53 & 1 & 3 \\
\hline Õpetajad ei arvesta iga üksiku õpilase vajadustega & 1,89 & 0,68 & 1 & 3 \\
\hline Õpetajate puudumine & 1,41 & 0,56 & 1 & 3 \\
\hline Õpetajate vastuseis muutustele & 1,84 & 0,74 & 1 & 4 \\
\hline Õpetajad on õpilastega liiga ranged & 1,76 & 0,59 & 1 & 3 \\
\hline Õpetajate hilinemine & 1,34 & 0,50 & 1 & 3 \\
\hline Õpetajad ei ole tundideks hästi valmistunud & 1,37 & 0,49 & 1 & 3 \\
\hline
\end{tabular}

Märkus. $M=$ keskmine tulemus; $S D=$ standardhälve; $\min =$ minimaalne tulemus; $\max =$ maksimaalne tulemus.

Tabel 8. Korrelatsioonikordajad ( $r$ ) õpilastepoolse õppetööd takistava käitumise agregeeritud muutuja ja õpetajatepoolse õppetööd takistava käitumise vahel

\begin{tabular}{l|c|c}
\hline Õpetaja käitumise tunnused & $\begin{array}{c}\text { Õpilastepoolne } \\
\text { õppetööd takistav } \\
\text { käitumine ala- } \\
\text { sooritajate grupis } \\
(\mathbf{N}=\mathbf{5 7 5})\end{array}$ & $\begin{array}{c}\text { Õpilastepoolne } \\
\text { oppetööd takis- } \\
\text { tav käitumine } \\
\text { ülesooritajate } \\
\text { grupis }(\boldsymbol{N}=\mathbf{5 8 1})\end{array}$ \\
\hline $\begin{array}{l}\text { Õpetajad peavad õpetama ühes ja samas klassis } \\
\text { erinevate võimetega õpilasi* }\end{array}$ & 0,17 & 0,34 \\
\hline $\begin{array}{l}\text { Õpilasi ei julgustata saavutama kogu oma } \\
\text { potentsiaali* }\end{array}$ & 0,41 & 0,32 \\
\hline Õpetajad ei ole tundideks hästi valmistunud & 0,29 & 0,37 \\
\hline $\begin{array}{l}\text { Õpetajad peavad õpetama ühes ja samas klassis } \\
\text { erineva etnilise taustaga (st keel, kultuur) õpilasi }\end{array}$ & 0,36 & 0,40 \\
\hline Õpetajad on õpilastega liiga ranged & 0,30 & 0,25 \\
\hline Õpetajate vastuseis muutustele & 0,32 & 0,36 \\
\hline
\end{tabular}




\begin{tabular}{l|c|c}
\hline Õpetaja käitumise tunnused & $\begin{array}{c}\text { Õpilastepoolne } \\
\text { oppetööd takistav } \\
\text { käitumine ala- } \\
\text { sooritajate grupis } \\
(\mathbf{N = 5 7 5 )}\end{array}$ & $\begin{array}{c}\text { Õpilastepoolne } \\
\text { oppetööd takis- } \\
\text { tav käitumine } \\
\text { ülesooritajate } \\
\text { grupis }(\boldsymbol{N}=\mathbf{5 8 1})\end{array}$ \\
\hline Õpetajate hilinemine & 0,37 & 0,40 \\
\hline Õpilaste ja õpetajate halvad suhted & 0,54 & 0,51 \\
\hline Õpetajate puudumine & 0,24 & 0,26 \\
\hline $\begin{array}{l}\text { Õpetajad ei arvesta iga üksiku õpilase } \\
\text { vajadustega }\end{array}$ & 0,40 & 0,43 \\
\hline Õpetajatel on õpilaste suhtes madalad ootused & 0,34 & 0,35 \\
\hline
\end{tabular}

Märkus. Kõik Pearsoni korrelatsioonikordajad on olulised nivool $p<0,01 ;{ }^{*}=$ korrelatsioonikordajate erinevus on oluline nivool $p<0,05$.

Õpilastepoolse õppetööd takistava käitumise agregeeritud muutuja ja õpetajatepoolse õppetööd takistava käitumise tunnuste vahel arvutati korrelatsioonid (tabel 8). Alasooritajate grupis ilmnes mõõdukas seos õpilastepoolse õppetööd takistava käitumise agregeeritud muutuja ja õpetajatepoolse õppetööd takistava käitumise järgmiste tunnuste vahel: õpilaste ja õpetajate halvad suhted ( $r=0,540)$, oppilasi ei julgustata saavutama kogu oma potentsiaali $(r=0,414)$, ópetajad ei arvesta iga üksiku ópilase vajadustega $(r=0,403)$. Seosed jäid üldjoontes samaks, kui võeti arvesse õpilase SES-tausta: ópilaste ja õpetajate halvad suhted $(r=0,534)$, oppilasi ei julgustata saavutama kogu oma potentsiaali $(r=0,415)$, õpetajad ei arvesta iga üksiku ópilase vajadustega $(r=0,404)$. Kõik eespool nimetatud korrelatsioonid olid olulised nivool $p<0,01$.

Ülesooritajate grupis oli mõõdukas seos õpetajate ja õpilaste käitumise vahel järgmiste tunnuste puhul: ópilaste ja ópetajate halvad suhted $(r=0,510)$, õpetajad ei arvesta iga üksiku ópilase vajadustega $(r=0,425)$, õpetajad peavad õpetama ühes ja samas klassis erineva etnilise taustaga (st keel, kultuur) ópilasi $(r=0,404)$. Tulemused ei muutunud eriti ka ülesooritajate grupis, kui võeti arvesse õpilaste sotsiaalmajanduslikku tausta: ópilaste ja oppetajate halvad suhted $(r=0,478)$, opetajad ei arvesta iga üksiku ópilase vajadustega $(r=0,419)$, opetajad peavad õpetama ühes ja samas klassis erineva etnilise taustaga (st keel, kultuur) ópilasi $(r=0,404)$. Need korrelatsioonid olid olulised nivool $p<0,01$.

Hinnati ka kahe grupi seoste erinevuse olulisust. Kahe grupi vahel osutusid oluliselt erinevaks ainult kaks tunnust. Tunnus õpetajad peavad õpetama ühes ja samas klassis erinevate võimetega ópilasi seostus õpilastepoolse 
õppetööd takistava käitumisega tugevamini ülesooritajate grupis. Seevastu tunnus ópilasi ei julgustata saavutama kogu oma potentsiaali seostus õpilastepoolse õppetööd takistava käitumisega tugevamini alasooritajate grupis.

Neljandale uurimisküsimusele ${ }^{8}$ leiti vastus regressioonanalüüsi käigus, kusjuures sõltuvaks muutujaks oli õpilastepoolse õppetööd takistava käitumise agregeeritud muutuja ja sõltuvateks tunnusteks õpetajatepoolse õppetööd takistava käitumise üksiktunnused. Õpetajatepoolse õppetööd takistava käitumise ja hoiakutega seotud tunnused kirjeldavad õpilastepoolse õppetööd takistava käitumise varieeruvusest alasooritajate grupis $46,2 \%$ ja ülesooritajate grupis $48,3 \%$ ulatuses. Arvestades õpilaste SES-tausta, on need protsendid alasooritajate grupis $54 \%$ ja ülesooritajate grupis 50\%.

Õpilaste SES-tausta arvessevõtmisel selgitasid alasooritajate grupis õpilaste käitumise varieeruvust järgmised statistiliselt olulised õpetajapoolset õppetööd takistavat käitumist iseloomustavad tunnused: 1) õpilaste ja õpetajate halvad suhted;2) õpetajad peavad õpetama ühes ja samas klassis erineva etnilise taustaga (st keel, kultuur) ópilasi; 3) ópetajad ei arvesta iga üksiku oppilase vajadustega; 4) õpetajad on ópilastega liiga ranged; 5) ópetajad ei ole tundideks hästi valmistunud; 6) ópetajate hilinemine; 7) õpetajate vastuseis muutustele. Neist esimesed viis kirjeldasid õpilase käitumise varieeruvust $50,5 \%$ ulatuses.

Ülesooritajate grupis olid statistiliselt olulised need õpetajapoolset õppetööd takistavat käitumist ja hoiakuid iseloomustavad tunnused, mis selgitavad õpilastepoolse õppetööd takistava käitumise varieeruvust. Need sarnanesid osaliselt alasooritajate grupi tulemustega: 1) ópilaste ja ópetajate halvad suhted; 2) oppetajad peavad ópetama ühes ja samas klassis erineva etnilise taustaga (st keel, kultuur) ópilasi; 3) ópetajad ei arvesta iga üksiku õpilase vajadustega; 4) õpetajad on ópilastega liiga ranged; 5) ópetajate hilinemine. Statistiliselt olulisteks osutusid selle grupi puhul veel 7) oppetajad peavad õpetama ühes ja samas klassis erinevate võimetega õpilasi; 8) ópetajate puudumine; 9) ópetajatel on oppilaste suhtes väikesed ootused. Viieks olulisimaks tunnuseks olid õpilaste ja ópetajate halvad suhted, ópetajad peavad õpetama ühes ja samas klassis erineva etnilise taustaga (st keel, kultuur) õpilasi, ópetajad ei arvesta iga üksiku õpilase vajadustega, ópetajate hilinemine ja õpetajad peavad ópetama ühes ja samas klassis erinevate võimetega õpilasi, mis kirjeldasid õpilase käitumise varieeruvust $43,3 \%$ ulatuses.

8 Kui palju kirjeldab õpilastepoolse õppetööd takistava käitumise varieeruvusest õpetajatepoolne õppetööd takistav käitumine? 


\section{Arutelu}

Uuringu eesmärk oli selgitada õpetajate toetava käitumise ja õpilasepoolse õppetööd takistava käitumise seoseid õpilaste õpitulemustega. Esimesele uurimisküsimusele vastuse leidmisel selgitati, milline seos on õpilaste tulemuste ja õpetajatepoolse õppetööd takistava käitumise vahel. Tulemused toetasid uurimusi, milles väidetakse, et õpetaja käitumine ja õpilaste tulemused on omavahel seotud, kuid praegune uurimus näitas õpetaja käitumise ja õpilaste tulemuste vahel väga nõrka seost. Sama kinnitas ka teine tulemus - prognoosijääkide põhjal leitud õpilaste üle- või alasoorituse ja õpetajatepoolse õppetööd takistava käitumise vahel puudus statistiliselt oluline seos (tabelid 4 ja 5). Koolijuhtide hinnangu järgi võiks arvata, et õpetajapoolne õppetööd toetavam käitumine ei ole õpilaste tulemuste parandamise seisukohalt väga oluline, kuid see on siiski väga ebatõenäoline ja vastuolus paljude teadustöödega selles valdkonnas. Pigem võib põhjus seisneda selles, et vähem edukate koolide juhtidel puudub kriitiline hinnang oma õpetajaskonna kohta. See võib olla tingitud tahtest näidata õpetajate käitumist positiivsemana või oskamatusest probleeme näha. Pisut üldistatumalt jõudsid Türk jt (2011) oma uurimuses samale seisukohale - mida nõrgemate tulemustega on kool, seda vähem näeb juht oma kooli nõrku külgi.

Vastates kolmandale uurimisküsimusele ning võrreldes õpetaja ja õpilaste käitumise seoseid kahe grupi vahel, saab selgema pildi, mille poolest võiks õpetajate käitumine erineda üle- ja alasooritajatega töötamisel (tabelid 6, 7 ja 8). Mõlema grupi puhul ilmnenud mõõdukad seosed õpilaste õppetööd takistava käitumise, õpetaja ja õpilaste halbade suhete ning õpilase individuaalsete vajaduste mittearvestamise vahel olid kooskõlas varasemate uuringutega. Mitmed uuringud on toonud esile, et head suhted, sealhulgas distsipliin, aitavad luua klassis positiivset õpikeskkonda, mis pakub võimalusi efektiivseks õppimiseks ja õpetamiseks (Schmitt et al., 2012; WilsonFleming \& Wilson-Younger, 2012).

Uuringu tulemus, mis näitas mõlemas grupis ilmnenud keskmise tugevusega seost õpilastepoolse õppetööd takistava käitumise ja õpilaste individuaalsete vajaduste mittearvestamise vahel, on samuti kooskõlas varasemate uurimustega. Uurimustes tuuakse esile, et õppetööd on võimalik tulemuslikumalt läbi viia ja toetada õpilaste arengut, kui õpilaste vajadusi võetakse arvesse ning muudetakse oma suhtumist ja hoiakuid (Anderson \& Stillman, 2013).

Kaasava hariduse põhimõtete elluviimise ja riikidevahelise inimeste mobiilsuse suurenemise tagajärjel on mõistetav, et klassis ja koolis võivad õppida erineva etnilise taustaga õpilased. Tulevikus võib Eesti õpetajaskond seista järjest enam silmitsi haridusprobleemidega, mis seonduvad mitme- 
kultuurilise õpilaskonna õpetamise ja kasvatamisega. Ülesooritajate grupis ilmnenud seos tunnuse puhul, mis käsitleb erineva etnilise taustaga õpilaste koosõpetamist, viitab arendamist nõudvale valdkonnale. Ülesooritajate grupis võivad õpilased olla võimetelt homogeensemad ja seetõttu võivad erineva etnilise taustaga õpilased teistest rohkem eristuda. Kusjuures eristumise põhjus ei pruugi olla õpilase võimekus, vaid õpetaja suutmatus õpilase eripära õppetöös arvesse võtta. Õpetajalt nõuab etnilisest taustast tingitud eripära arvestamine õppetöös suuremat professionaalsust. Näiteks on Tago ja Ots (2010) viidanud, et kakskeelsed õpilased kalduvad näitama nõrgemaid akadeemilisi tulemusi, seejuures ei ole nõrgemad tulemused põhjustatud väiksemast võimekusest, vaid neid toetava õpikeskkonna nõrkusest. Alasooritajate grupis võivad erineva etnilise taustaga õpilased sulanduda vähem võimekate või koduse toeta õpilaste hulka, mistõttu õpetajad ei pruugi tajuda õpilase etnilisest taustast tulenevaid vajadusi.

Alasooritajate grupis ilmnes olulise tulemusena õpilaste vähene julgustamine oma potentsiaali avamisel. Tõlgenduse leidmiseks peaks esitama küsimuse, miks õpetajad ei toeta õpilast. Alasooritajate puhul võib arvata, et õpetajal on madalad ootused õpilaste suhtes, mistõttu ta ei pea õpilase toetamist vajalikuks. Jõgi jt (2014) on leidnud, et õpetajate võimekususkumused ja tulemusootused mõjutavad õpetamist ning õpilaste motivatsiooni suunamist. Rozansky ja Aagesen (2010) on kinnitanud, et õpilaste julgustamine mõjutab lugemisoskuse paranemist. Eesti kuulub PISA uuringu järgi riikide hulka, kus õpilased saavutavad eluks vajalikud alusoskused. Tipptulemusi saavutanud riikidega võrreldes on aga nende õpilaste osakaal, kes suudavad lahendada keerukamaid ja teadmisi nõudvaid ülesandeid, oluliselt väiksem (OECD, 2013a). Kui võtta aluseks koolijuhtide antud hinnang õpetaja tegevusele, mis puudutab õpilaste julgustamist nende potentsiaali avamisel, ilmneb, et Eesti on PISA 2012 uuringus osalenud riikide järjestuses üsna tagasihoidlikul kohal - 40. kohal 65 riigi hulgas (OECD, 2013c). Eelneva põhjal võib oletada, et kui õpetajad oskaksid suhtuda õpilaste võimetesse adekvaatsemalt ja suudaksid kõigi suhtes püstitada kõrged ootused, võiks see aidata õpilastel oma potentsiaali senisest edukamalt välja arendada.

Tunnuse õpetajad peavad õpetama ühes ja samas klassis erinevate võimetega õpilasi esilekerkimist ülesooritajate grupis võib põhjendada asjaoluga, et vaatlusalustes koolides on teadvustatud erinevate võimetega õpilaste olemasolu ja nende õpetamist ühes klassis peetakse loomulikuks. Selle grupi keskmine sooritus oli statistiliselt oluliselt parem, seega võib eeldada, et kui koolis peetakse loomulikuks erineva võimekusega õpilaste koosõpetamist ning õpetajatel on asjaomased teadmised ja oskused, on ka õpilaste tulemused nende SES-taseme kontekstis paremad. Seevastu alasooritajate 
grupi puhul võiks väita, et suhteliselt halvema akadeemilise tulemuse üks põhjuseid on asjaolu, et õpetaja ei saa hakkama erineva võimekusega õpilaste koosõpetamisel. Võimetelt heterogeense klassi õpetamisega mittetoimetulek vajab edasist uurimist. Eestis on seda ka juba uuritud, näiteks on Seepter (2014) oma uurimuses välja toonud, et vaimse võimekuse mõttes heterogeensetes klassides on ka andekaid eesti- ja kakskeelseid lapsi, kelle vaimne potentsiaal akadeemilises plaanis ei realiseeru. See võib olla seotud nii hoiakutega kui ka vajakajäämistega didaktilistes oskustes. Ka praegusest uurimusest ilmnes, et alasooritajate grupi puhul on õpetajad vähem altid õpilasi toetama. On üsna selge, et kui õpetajal pole piisavalt pedagoogilisi ja psühholoogilisi oskusi õpilaste individuaalsuse arvestamisel ja puudub tahe õpilasi oma hoiakute tõttu toetada, siis pole ka õpilaste tulemused väga head või ei realiseeri nad oma võimeid.

Põhjused, miks mõnes koolis saavad õpilased paremaid tulemusi, kui võiks eeldada nende SES-tausta põhjal, on erinevad. Tulemused näitavad, et õpilaste ülesoorituse võimalikuks mõjuteguriks on õpetaja suutlikkus õpetada võimetelt erinevaid õpilasi. Teine oluline tegur on õpetaja julgustav hoiak õpilaste suhtes, sest nii toetatakse kõigi õpilaste arengupotentsiaali väljaarendamist. Koolides, kus õpetajatel eelnimetatud oskused puuduvad, võivad õpilased saada nõrgemaid õpitulemusi, kui nende võimed võimaldaksid.

Uurimuse piirangutena võib välja tuua järgmised aspektid: õpetajate ja õpilaste käitumise tunnustena on kasutatud PISA uuringu raames antud koolijuhtide hinnanguid. Samuti on kasutatud PISA 2012 uuringu tarbeks välja arvutatud õpilaste sotsiaalmajandusliku tausta indeksit ning matemaatika, loodusteaduste ja lugemise soorituse keskmist. Valimis on ainult eesti õppekeelega koolide õpilased, vene õppekeelega koolide õpilased on uuringust välja jäetud, mistõttu ei saa teha üldistusi kogu Eesti kohta.

\section{Kokkuvõte}

Sageli tuuakse õpilaste nõrkade tulemuste põhjuseks ettekääne, et õpilaste vanemad pole piisavalt toetavad ega hoolivad. Praegune uuring näitas, et koole saab mikrokliima valdkonnas mõningate tunnuste poolest siiski eristada. Õppetöö seisukohalt on oluline õpetaja ainealane professionaalsus, aga sama olulised on tema väärtused ja hoiakud ning nende põhjal väljakujunenud käitumine õpilastega. Uuringu tulemused osutavad, et kooli juhtimisel on tähtis jälgida, kas õpetaja käitumine on õpilast toetav või mitte. Õpetaja käitumine mõjutab õpilase akadeemilist tulemuslikkust otseselt ja kaude, kujundades õpilase suhtumist ja avaldades mõju õppimist mõjutavatele (takistavatele) tegevustele. Praeguste ja varasemate uurimistulemuste 
põhjal võib öelda, et kooli panus õpilaste arengusse seostub koolis valitseva mikrokliimaga. Mikrokliima tähtsus tuleb ilmsiks nii ala- kui ka ülesooritajate hulgas: samad tegurid (nt õpilaste ja õpetajate suhted ning õpilase vajadustega arvestamine õppetöös) seostuvad õpilastel óppetööd takistavate käitumisviiside esinemisega. Koolid saavad arvesse võtta eelkirjeldatud olulisi aspekte õpetajate käitumises, et muuta õpikeskkond selliseks, mis toetaks õppimist, ja tagada iga õpilase võimetekohane areng.

\section{Tänusõnad}

Uuringu läbiviimist ja artikli kirjutamist on toetanud Euroopa Sotsiaalfondi programm Eduko SA Archimedese kaudu (grant nr 30.1-5.5/224-1) ning haridus- ja kasvatusteaduste doktorikool.

\section{Kasutatud kirjandus}

Anderson, L. M., \& Stillman, J. A. (2013). Student teaching's contribution to preservice teacher development: A review of research focused on the preparation of teachers for urban and high-needs contexts. Review of Educational Research, (83)1, 3-69. doi: http://dx.doi.org/10.3102/0034654312468619

Baird, K. (2012). Class in the classroom: The relationship between school resources and math performance among low socioeconomic status students in 19 rich countries. Education Economics, 20(5), 484-509. doi: http://dx.doi.org/10.1080/09645292.2010.511848

Bodovski, K., Nahum-Shani, I., \& Walsh, R. (2013). School climate and students' early mathematics learning: Another search for contextual effects. American Journal of Education, 119(2), 209-234. doi: http://dx.doi.org/10.1086/667227

Brookover, W. B., Schweitzer, J. H., Schneider, J. M., Beady, C. H., Flood, P. K., \& Wisenbaker, J. M. (1978). Elementary school social climate and school achievement. American Educational Research Journal, 15(2), 301-318. doi: http://dx.doi.org/10.3102/00028312015002301

Brown, G. J., \& Henry, D. (1992). Using the climate survey to drive school reform. Contemporary Education, 63(4), 277-280.

Caldarella, P., Shatzer, R. H., Gray, K. M., Young, K. R., \& Young, E. L. (2011). The effects of school-wide positive behaviour support on middle school climate and student outcomes. Research in Middle Level Education Online, 35(4), 1-14.

Capern, T., \& Hammond, L. (2014). Establishing positive relationships with secondary gifted students and students with emotional/behavioural disorders: Giving these diverse learners what they need. Australian Journal of Teacher Education, 39(4), 46-67. doi: http://dx.doi.org/10.14221/ajte.2014v39n4.5

Cohen, J. (2006). Social, emotional, ethical, and academic education: Creating a climate for learning, participation in democracy, and well-being. Harvard Educational Review, 76(2), 201-237. 
Cohen, J., \& Elias, M. (2010). School climate: Building safe, supportive and engaging classrooms \& schools. Port Chester: National Professional Resources.

Cohen, J., McCabe, L., Michelli, N. M., \& Pickeral, T. (2009). School climate: Research, policy, practice, and teacher education. Teachers College Record, 111(1), 180-213.

Devine, J., \& Cohen, J. (2007). Making your school safe: Strategies to protect children and promote learning. New York: Teachers College Press.

Feldman, R. S., \& Theiss, A. J. (1980). The teacher and student as Pygmalions: Joint effects of teacher and student expectations. Journal of Educational Psychology, 74(2), 217-223. doi: http://dx.doi.org/10.1037/0022-0663.74.2.217

Freiberg, H. J. (Ed.) (1999). School climate: Measuring, improving and sustaining healthy learning environments. London: Falmer Press.

Ganzeboom, H. B. G., Graaf, De P. M., \& Treiman, D. J. (1992). A standard international socio-economic index of occupational status. Social Science Research, 21(1), 1-56. doi: http://dx.doi.org/10.1016/0049-089X(92)90017-B

ILO (1990). ISCO-88: International standard classification of occupations. Geneva: International Labour Office.

Jõgi, A-L., Aus, K., \& Kikas, K. (2014). Esimese klassi õpilaste matemaatikateadmiste arengu seosed klassiõpetajate võimekususkumuste ja tulemusootuste profiiliga. Eesti Haridusteaduste Ajakiri, 2(1), 50-66. doi: http://dx.doi.org/10.12697/eha.2014.2.1.03

Kitsing, M., Ploom, K., \& Kukemelk, H. (2013). Evaluation of teachers and PISA 2009 results in Estonia. British Journal of Education, Society \& Behavioural Science, 3(3), 195-205. doi: http://dx.doi.org/10.9734/BJESBS/2013/2510

Klein, J., Cornell, D., \& Konold, T. (2012). Relationships between bullying, school climate, and student risk behaviours. School Psychology Quarterly, 27(3), 154-169. doi: http://dx.doi.org/10.1037/a0029350

Loukas, A. (2007). What is school climate? Leadership Compass, 5(1). Retrieved from http://www.naesp.org/resources/2/Leadership_Compass/2007/LC2007v5n1a4.pdf.

Null, C. F. (2013). The impact of an economically disadvantaged student population on school climate (Doctoral thesis). Houston: University of Houston. Retrieved from http://repositories.tdl.org/uh-ir/bitstream/handle/10657/603/NULL-DISSERTATION-2012.pdf? sequence $=1$.

OECD (1999). Classifying educational programmes: Manual for ISCED-97 implementation in OECD countries. Retrieved from http://www.oecd.org/education/skills-beyond-school/1962350.pdf.

OECD (2013a). PISA 2012 results: What students know and can do (Vol. 1). OECD Publication.

OECD (2013b). PISA 2012 results: Excellence through equity (Vol. 2). OECD Publication.

OECD (2013c). PISA 2012 results: What makes schools successful? (Vol. 4). OECD Publication.

Osler, A. (2010). Students' perspectives on schooling. Maidenhead: Open University Press. Patton, G. C., Bond, L., Carlin, J. B., Thomas, L., Butler, H., Glover, S., ... Bowes, G. (2006). Promoting social inclusion in schools: A group-randomized trial of effects on student health risk behavior and well-being. American Journal of Public Health, 96(9), 1582-1587. doi: http://dx.doi.org/10.2105/AJPH.2004.047399

Robinson, V., Hohepa, M., \& Lloyd, C. (2009). School leadership and student outcomes: Identifying what works and why: Best evidence synthesis. New Zealand: Ministry of Education of New Zealand. 
Rozansky, C. L., \& Aagesen, C. (2010). Low-achieving readers, high expectations: Image theatre encourages critical literacy. Journal of Adolescent \& Adult Literacy, 53(6), 458-466. doi: http://dx.doi.org/10.1598/JAAL.53.6.2

Ruus, V.-R., Veisson, M., Leino, M., Ots, L., Pallas, L., Sarv, E.-S., \& Veisson, A. (2007). Students' well-being, coping, academic success, and school climate. Social Behavior and Personality, 35(7), 919-936. doi: http://dx.doi.org/10.2224/sbp.2007.35.7.919

Scanlon, G., \& Barnes-Holmes, Y. (2013). Changing attitudes: Supporting teachers in effectively including students with emotional and behavioural difficulties in mainstream education. Emotional \& Behavioural Difficulties, 18(4), 374-395. doi: http://dx.doi.org/10.1080/13632752.2013.769710

Schmitt, M. B., Pentimonti, J. M., \& Justice, L. M. (2012). Teacher-child relationships, behavior regulation, and language gain among at-risk preschoolers. Journal of School Psychology, 50(5), 681-699. doi: http://dx.doi.org/10.1016/j.jsp.2012.04.003

Seepter, K. (2014). Õpilase vaimse võimekuse ja klassi õpikeskkonna seos akadeemilise edukusega kakskeelsetel ja nendega koos õppivatel eestikeelsetel. Eesti Haridusteaduste Ajakiri, 2(1), 186-216. doi: http://dx.doi.org/10.12697/eha.2014.2.1.03

Shepard, J., Salina, C., Girtz, S., Cox, J., Davenport, N., \& Hillard, T. L. (2012). Student success: Stories that inform high school change. Reclaiming Children and Youth, 21(2), 48-53.

Tago, M., \& Ots, A. (2010). Pupils who speak a „wrong language”: Bilingual children's academic achievement in submersion education. In A. Toomela (Ed.), Systemic person-oriented study of child development in early primary school (pp. 133-154). Frankfurt am Main: Peter Lang.

Tire, G., Lepmann, T., Jukk, H., Puksand, H., Henno, I., Lindemann, K., Kitsing, M., ... Lorenz, B. (2013). PISA 2012 Eesti tulemused. Tallinn: SA Innove.

Täht, K. (2012). The cross-cultural view on students' motivation to learn (Doctoral dissertation). Tartu: University of Tartu. Retrieved from http://dspace.utlib.ee/dspace/ bitstream/handle/10062/28154/taht_karin_2.pdf?sequence=5.

Türk, K., Haldma, T., Kukemelk, H., Ploom, K., Irs, R., \& Pukkonen, L. (2011). Üldharidus- ja kutsekoolide tulemuslikkus ja seda mõjutavad tegurid. Tartu Ülikool, Haridus- ja Teadusministeerium. Külastatud aadressil https://riigikantselei.ee/sites/ default/files/content-editors/TOF/TOF_uuringud/10_koolitulemusjuhtimine20111.pdf.

Voltri, O., Luik, P., \& Taimalu, M. (2013). Õpetajakoolituse praktikantide ja kutseaastal olevate õpetajate kutsevalikut mõjutavad motivatsioonitegurid. Eesti Haridusteaduste Ajakiri, 1, 97-123. doi: http://dx.doi.org/10.12697/eha.2013.1.06

Wang, W., Vaillancourt, T., Brittain, H. L., McDougall, P., Krygsman, A., Smith, D., ... \& Hymel, S. (2014). School climate, peer victimization, and academic achievement: Results from a multi-informant study. School Psychology Quarterly, 29(3), 360-377. doi: http://dx.doi.org/10.1037/spq0000084

Willmore, E. L. (2006). Learning environments. In W. Fenwick (Ed.), Encyclopedia of educational leadership and administration (2nd ed., Vol. 2, pp. 607-608). Thousand Oaks: Sage Publications. doi: http://dx.doi.org/10.4135/9781412939584.n339

Wilson-Fleming, L., \& Wilson-Younger, D. (2012). Positive classroom environments = Positive academic results. Retrieved from http://www.eric.ed.gov/contentdelivery/servlet/ERICServlet?accno = ED536465. 


\title{
School microclimate: Teachers' supportive behaviour and student performance
}

\author{
Maie Kitsing ${ }^{a 1}$, Karin Täht ${ }^{b}$, Hasso Kukemelk ${ }^{a}$ \\ ${ }^{a}$ University of Tartu, Institute of Educational Sciences \\ ${ }^{b}$ University of Tartu, Institute of Psychology
}

\begin{abstract}
Summary
School microclimate is an essential factor that influences student performance. The current study focuses on two subtopics of school microclimate. The aim of this study is to investigate the relationship between teachers' supportive behaviour and student performance taking into account student's social, economic, and cultural status. The research questions were as follows: 1. Is there a relationship between learning process hindering types of behaviour among teachers and student performance?

2. Is there a relationship between learning process hindering types of behaviour among teachers and students' predicted performance residuals (performance prediction based on students' socio-economic background (SES))?
\end{abstract}

3. Is there a relationship between learning process hindering types of behaviour among teachers and students in the selected groups? The groups were selected by residuals (student performance was predicted by their socio-economic status.)

4. Is the relationship similar for learning process hindering types of behaviour among teachers and low and underperforming groups of students?

5. To what extent does teacher behaviour describe the variation range of student behaviour?

School microclimate is one of the most important factors in creating the favourable learning environment. On the one hand, school microclimate has an influence on how well students master knowledge and skills as well as emotional, aesthetic and social competencies (Bodovski et al., 2013; Cohen \& Elias, 2010). On the other hand, school microclimate affects teacher's work and communication at school (Caldarella et al., 2011; Willmore, 2006). Numerous studies have indicated that the positive school climate

1 Institute of Educational Sciences, Faculty of Social Sciences and Education, University of Tartu, Salme 1a, 50103 Tartu, Estonia; maie.kitsing@hm.ee 
is associated with and/or predictive academic achievement, school success and effective violence prevention (Bodovski et al., 2013; Cohen et al., 2009).

Estonia participated in PISA 2012 and Estonian students ranked among the best performers (OECD, 2013a). Compared to other countries the performance gap between schools in Estonia was not big, but when we compare schools at the national level, the variation between schools is nevertheless noticeable. Mean scores between the strongest and weakest schools differed considerably (Tire et al., 2013). Therefore, it is vital to consider areas that make it possible to ensure positive development for all students.

This quantitative research using PISA 2012 data involves the following terms: school climate (teacher and student behaviour), general education performance (GEPs, the average mean score in reading, science and mathematics), and student socio-economic status (OECD, 2013a). PISA 2012 provided information about the school climate, describing student behaviour, as well as teacher behaviour, in connection to what extent the learning of students was hindered.

The sample used for PISA 2012 consisted of students from schools with Estonian language of instruction. Students were divided into three groups based on their socio-economic background (SES) and their predicted performance residuals:

1. Students whose mean score was weaker than their SES background would predict (further referred to as the low-performing group);

2. Students whose mean score was close to the predicted performance;

3. Students whose mean score was higher than their expected mean score (further referred to as the under-performing group).

The criterion for distinguishing the average of the group members was one standard deviation of the residuals. The total sample consisted of 3570 students ( $50 \%$ girls) and the respective school principals $(N=147)$.

In this study we have used four variables from PISA 2012: 1) The general education performance (GEPs was the average mean score in reading, science and mathematics); 2) The index of students' economic, social and cultural status; 3 ) The index of student-related factors affecting school microclimate which was derived from the school principals' reports on the extent to which the learning of students was hindered; 4) the teacherrelated factors affecting the school microclimate which were derived from school principals' reports on the extent to which the learning of students was hindered.

It appeared from the analysis that the correlation between GEPs and teacher behaviour in connection to what extent the learning of students was 
hindered was very low, but statistically significant. The correlation of the group of under-performing students was not statistically significant.

Based on the current study we can argue that in the Estonian case teachers' supportive behaviour is not a very essential factor promoting student performance. At the same time, we can interpret this finding as if Estonian principals are not very critical towards the behaviour of their teachers. The reasons for this are unclear; it is possible that the school principals are not critical enough or they do not want to acknowledge problematic areas in teacher behaviour (Türk et al., 2011). The principals of lower performing schools do not recognise schools' weaknesses.

The results showed that the moderate correlations in underperforming and low-performing student groups between students and teachers behaviour featured the following: poor student-teacher relations (low-performing group $r=.540$; underperforming group $r=.510$ ) and teachers not meeting individual students' needs (low-performing group $r=.403$; underperforming group $r=.425$ ). Additionally, moderate correlation was found between student and teacher behaviour in the low-performing group: students not being encouraged to achieve their full potential $(r=.414)$ and teachers having to teach students of diverse ethnic backgrounds in the underperforming groups $(r=.404)$. Comparing the relationships from groups' of underperforming and low-performing students, we found that only two features were statistically significant: students not being encouraged to achieve their full potential and teachers having to teach students of heterogeneous ability levels within the same class.

The study results revealed that it is crucial for school management to observe whether teachers' behaviour supports student or not. The role of school microclimate can be observed among both underperforming and low-performing: the same variables (i.e. student teacher relationship and considering the needs of the student in the study process) are associated with occurrences of hindering behaviour of student learning. The study showed that dealing effectively with students with special educational needs is also important to successful students.

Keywords: student behaviour, teacher behaviour, PISA, school microclimate, student socio-economic status (SES) 